Teologia Praktyczna 20(2019)

doi: $10.14746 /$ tp.2019.20.01

ORCID: 0000-0002-2746-5030

ANDREAS MÜLLER

\title{
Motywy działalności charytatywnej w Kościele starożytnym
}

„Zaiste, bracia najmilsi, miłosierdzie - to cnota prawdziwie Boskiej wspaniałości!” (Cyprian, XXVI) - takie i podobne wypowiedzi często pojawiały się w nauczaniu chrześcijańskim od III wieku. Skąd brało się to wielkie zaangażowanie, z jakim tacy pisarze kościelni, jak cytowany wyżej biskup Cyprian z Kartaginy, nawoływali do czynnej miłości?

Odpowiedź na to pytanie wymaga cofnięcia się do początków chrześcijańskiej dobroczynności, nazywanej dziś zazwyczaj diakonią lub działalnością charytatywną. Motywy i wzorce działalności diakonicznej są - jak dotąd - słabo przebadane. W XIX wieku, gdy Gerhard Uhlhorn (1826-1901), ewangelicki teolog z Loccum, wskazywał jeszcze na miłość bliźniego jako szczególny impuls do dobroczynności, odróżniający chrześcijaństwo od świata pogańskiego, badania nad tym obszarem zaczęły skupiać się coraz bardziej na kwestiach historyczno-instytucjonalnych lub po prostu na „faktach”. Dlatego też jeden z najwybitniejszych teologów luterańskich, Adolf von Harnack (1859-1930), w swoim arcydziele Mission und Ausbreitung des Christentums, wydanym po raz pierwszy w 1902 roku, ograniczył się jedynie do lapidarnej uwagi: „Decydujące jest ustalenie, co rzeczywiście dokonało się w obszarze działalności charytatywnej i świadczenia pomocy potrzebującym [...]" (Harnack 1902, s. 176) ${ }^{1}$.

Nie da się jednak zgłębić istoty diakonii okresu późnej starożytności, skupiając się niemalże wyłącznie na instytucjach i akcjach. Dlatego najistotniejsze jest tu pytanie o to, co od samego początku pobudzało chrześcijan do

${ }^{1}$ A. Harnack zaznacza, że jego dzieło to historia misji i dlatego liczą się dla niego fakty. Kwestie podejmowane w tym artykule wchodziłyby, według Harnacka, bardziej w zakres etyki chrześcijańskiej. 
angażowania się na rzecz drugiego człowieka. Przede wszystkim zaś należałoby zapytać, jak ludzie, mentalnie jeszcze głęboko zakorzenieni w antycznym świecie pogańskim, znajdowali motywację do działalności diakoniczno-charytatywnej.

Źródła, z których czerpano motywację do takiej działalności, były już w antyku i późnym antyku bardzo obszerne. Wielu znanych ojców Kościoła - począwszy od Cypriana z Kartaginy - pisało mowy na temat jałmużny i uczynków miłosiernych, w których starali się uzasadnić konieczność posługi diakonicznej. Kilka $\mathrm{z}$ tych linii argumentacyjnych postaram się przedstawić w sposób systematyczny.

\section{Biblijne uzasadnienia dobroczynności}

Kościół starożytny posługiwał się licznymi tekstami biblijnymi dla uzasadnienia dobroczynności. W wielu z nich znajdziemy bezpośrednie wezwania do indywidualnego zaangażowania charytatywnego. Nie są to bynajmniej jedynie teksty ze Starego Testamentu, jak np. Iz 58,7: „[Czyż nie jest raczej postem, który ja wybieram:] dzielić swój chleb z głodnym, do domu wprowadzić biednych tułaczy, nagiego, którego ujrzysz, przyodziać i nie odwrócić się od współziomków"2. Podobne wezwania znajdziemy również w Nowym Testamencie, jak np. w Jezusowym Kazaniu na górze: „Błogosławieni miłosierni, albowiem oni miłosierdzia dostąpią" (Mt 5,7)3. Rzadziej w Kościele starożytnym wskazywano na miłosiernego Samarytanina jako wzór postawy diakonicznej (Łk 10,25-37). Kilka zaś tekstów pojawiało się zawsze w kontekście zachęty do dawania jałmużny, jak np. opowieść o bogatym młodzieńcu (Mk 10,17-30; por. Grzegorz z Nazjanzu XIV. 39), który stał się wzorem (niestety nie zawsze całkowitej) rezygnacji z posiadania dóbr doczesnych i który - jak pokazuje tradycja - znalazł, zwłaszcza wśród ascetów, radykalnych naśladowców (por. Atanazy Aleksandryjski). Podczas gdy w tekście tym rezygnacja $\mathrm{z}$ dóbr doczesnych wiąże się $\mathrm{z}$ wieczną nagrodą $\mathrm{w}$ niebie, to inne miejsca w Biblii służą niejako do nadania wymiaru transcendentnego doczesnej działalności charytatywnej. Rozdział 25 Ewangelii św. Mateusza, według którego czyniący dobro spotykają samego Chrystusa w ubogich, chorych i potrzebujących, wynosi niejako caritas do poziomu służby Bożej ${ }^{4}$. Ponadto opisy życia pierwszych wspólnot chrześcijańskich, opartych na więzach wza-

\footnotetext{
${ }^{2}$ Słowa te przywołuje Grzegorz z Nazjanzu (XIV, 38). Wszystkie cytaty biblijne według: $P i$ smo Święte Starego i Nowego Testamentu (Biblia Tysiaclecia). (2002). Poznań (przyp. thum.).

${ }^{3} \mathrm{Na}$ ten cytat powołuje się również Grzegorz z Nazjanzu.

${ }^{4}$ Taką interpretację tego tekstu znajdziemy np. u Grzegorza z Nazjanzu (40). Na Mt 25 chętnie powołuje się też Cyprian (XXIInn).
} 
jemnej miłości, a także tekst z Dziejów Apostolskich na temat działalności diakona Szczepana, miały ogromne znaczenie dla rozwoju chrześcijańskiej dobroczynności (Cyprian, XXV) ${ }^{5}$. Recepcja tych tekstów została już mniej lub bardziej wyczerpująco omówiona w wielu innych pracach i nie wymaga w tym miejscu szczegółowego przedstawienia. Skupmy się zatem najpierw na ustaleniu głównych paradygmatów teologicznych działalności charytatywnej w Kościele starożytnym. Dominujące będzie tu uzasadnienie soteriologiczne.

\section{Jałmużna ratuje duszę}

Przekonanie o tym, że bogactwo i przepych są przyczyną niepotrzebnych, bezsensownych trosk, stale powraca w literaturze patrystycznej (por. Grzegorz z Nazjanzu, 16). Zdają się one wręcz powodować chorobę duszy (por. Grzegorz z Nazjanzu, 18). Dlatego ojcowie Kościoła raz po raz wzywają do tego, by gromadzić swoje skarby nie w niepewnej teraźniejszości, a w przyszłości (por. Grzegorz z Nazjanzu, 19nn). Chodzi tu nie o dobra przemijające, lecz nieprzemijające. Jałmużna ratuje niejako duszę (por. Grzegorz z Nazjan$\mathrm{zu}, 21-22)$.

Przekonanie o tym, że miłosierdzie prowadzi do zbawienia, znaleźć można już u Cypriana z Kartaginy. Jego linia argumentacji jest właściwie czymś w rodzaju chrystianizacji pogańskiej maksymy do ut des (daję, abyś dawał). Zaś w Drugim Liście św. Klemensa Rzymskiego do Koryntian z połowy II wieku znaleźć można przeświadczenie, że jałmużna sprzyja przebaczeniu grzechów,

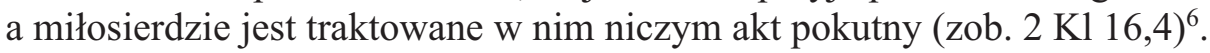

Ważną rolę w tym kontekście odgrywa wyobrażenie ubogich jako ołtarza Bożego. Kto ich wspiera, zyskuje w gruncie rzeczy łaskę dla samego siebie. Myśl taką znajdziemy już w II wieku u św. Polikarpa. Nie zanikła ona bynajmniej w późniejszej literaturze chrześcijańskiej. Święty Jan Chryzostom powiedział o ubogich: „Gdy otrzymują, wówczas swymi modlitwami przejednują Boga. Zamiast barbarzyńskich napadów odpierają ataki demonów" (Jan Chryzostom, LXVI, 4; Mt 20,29-21,11).

Zwłaszcza św. Cyprian rozwinął koncepcję, w której, korzystając także z pogańskich wyobrażeń, ukazał, dlaczego warto dawać jałmużnę. W czasach, gdy ludzie żyli głęboko przeniknięci nadzieją zbawienia, Cyprian dowodził,

\footnotetext{
${ }^{5}$ Według Cypriana, chrześcijanie oddawali całe swoje mienie, ażeby zebrać owoce wiecznych posiadłości.

${ }^{6}$ Zob. Pierwsi świadkowie. Pisma Ojców Apostolskich. (1998). W tekście oryginalnym myśl

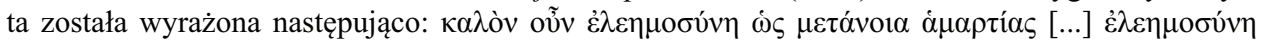

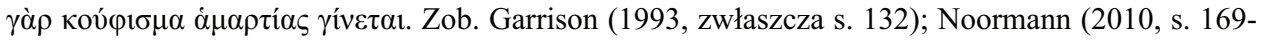
$-191)$.
} 
że można je osiągnąć przez jałmużnę. W świecie naznaczonym klęskami żywiołowymi i prześladowaniami chrześcijan, powołując się na Prz 15,27 (Wulgata), podkreślał, że miłosierdzie oczyszcza z grzechów. Nawet łaskę chrztu może przywrócić pilne i gorliwe spełnianie uczynków miłosierdzia (Cyprian, II).

Przy końcu swego dzieła De opere et eleemosyna (O uczynkach miłosiernych i jatmużnie) biskup Kartaginy podejmował refleksję nad jałmużną w kontekście popularnych wówczas pogańskich widowisk (łac. munera), wspieranych przez ważne osobistości ogromnymi datkami - przede wszystkim po to, by zyskać uznanie w oczach ówczesnych możnych (Cyprian, XXI). Takie darowizny były początkiem niejednej kariery politycznej. Cyprian podkreślał w tym kontekście, że jałmużna może być wspanialszym i chwalebniejszym widowiskiem, zaadresowanym do samego Boga. Takie przedstawienie (łac. munus) wymaga zdecydowanie większych nakładów niż „chleb i igrzyska”, skierowane jedynie na zdobycie uznania u ludzi. W przypadku jałmużny nie chodzi bowiem o otrzymanie w zamian wozu tryumfalnego, zarezerwowanego dla wyższych urzędników cesarza, ani też godności konsula, lecz o życie wieczne ${ }^{7}$. Cyprian argumentował w sposób klasyczny, nawiązując do godności człowieka antycznego. Jałmużna nie służy zatem pozyskaniu próżnej i przemijającej przychylności (łac. favor) ludu, lecz nagrody (łac. praemium) wieczystego królowania w niebie. Cyprian dokonał tu niezwykłej transformacji antycznych pogańskich wyobrażeń poprzez transcendowanie i eschatologizację zasady, na której opierały się owe munera.

Soteriologicznego uzasadnienia dobroczynności można w pewnym sensie doszukiwać się także w przekonaniu, że człowiek czyniący miłosierdzie nie tylko osiągnie chwałę z Bogiem w niebie, lecz także jako miłujący człowieka, jako philanthropos, stanie się nieco podobnym Bogu, względnie bogom - jeśli jest poganinem. Zaczątki tej myśli znajdziemy również u Cypriana, który mówił o tym, że miłosierny staje się dzieckiem Bożym przez to, że naśladuje dobroć (łac. bonitas) i szczodrość (łac. largitas) Boga (Cyprian, XXI). Argumentacja ta była kontynuowana zwłaszcza u greckich ojców Kościoła w nauce o przebóstwieniu, theosis. Kto zatem miłuje człowieka i dobrze czyni, ten postępuje niczym Bóg, staje się niejako Bogiem ${ }^{8}$.

Takie motywy diakonii czynią z niej niestety - dla protestantów trudną do zaakceptowania - formę sprawiedliwości z uczynków. W Kościele starożyt-

\footnotetext{
${ }^{7}$ Podobną argumentację znajdziemy ponad 150 lat później u Jana Chryzostoma: „A ty, który siejesz nie w takiej, lecz w o wiele większej nadziei i masz wręczyć srebro samemu Chrystusowi, żebyś się miał cofać i drętwieć i zasłaniać ubóstwem?" (Jan Chryzostom, 5).

${ }^{8}$ Jan Chryzostom w swojej Mowie o jatmużnie, 6 cytuje Ewangelię św. Mateusza 5,45, wzywając chrześcijan do dobroczynności podobnej do dobroczynności samego Boga. Co ciekawe, Chryzo-

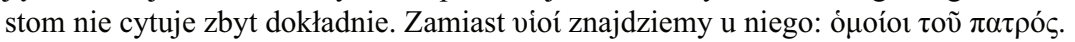


nym da się jednak znaleźć również takie linie argumentacji, które są przede wszystkim zwrócone w stronę adresata dobroczynności, przez co stają się jeszcze bardziej interesujące dla współczesnego dyskursu.

\section{III. „Chwalmy wdzięczną i cierpliwie znoszoną nędzę!”}

Na szczególną uwagę zasługuje w tym względzie argumentacja, w pierwszym rzędzie antropologiczna, Grzegorza z Nazjanzu, za pomocą której uzasadniał on troskę o ubogich, chorych i potrzebujących w swojej mowie XIV O miłości do biednych, wygłoszonej ok. 373 roku w Cezarei Kapadockiej, gdzie angażował się przede wszystkim w opiekę nad chorymi na trąd. Nawiązywał w niej głównie do tradycyjnego rozumienia katalogu cnót, mieszając przy tym jednak cnoty biblijne $\mathrm{z}$ pogańskimi i nie podejmując oddzielnej refleksji nad nimi (por. Grzegorz z Nazjanzu, 1).

Niemniej w celu uzasadnienia czynnej miłości bliźniego Kapadocczyk nie zatrzymywał się na prostych katalogach cnót. Jego mowa zawiera wielką pochwałę stworzoności i cielności człowieka: Ciało jest „przyjaznym wrogiem” i jednocześnie „wrogim przyjacielem” (zob. Grzegorz z Nazjanzu, 7). Jego słabości służą człowiekowi do realistycznej samooceny. Choroba i cierpienie są zatem - według Grzegorza - niemalże koniecznymi elementami tej stworzoności, bez których człowiek stworzony na obraz i podobieństwo Boże popadłby w pychę. Chorzy mają przypominać pozostałym ludziom o ich własnych słabościach; mają nas „uchronić przed takim przywiązaniem do teraźniejszości i tego, co zmysłowe, jak gdyby miały one nigdy nie przeminąć” (Grzegorz z Nazjanzu, 12).

Rezygnując z klasycznego, negatywnego spojrzenia na chorobę i cierpienie, Grzegorz stara się wydobyć z tych fenomenów coś pozytywnego. Pełnią one bardzo konkretną funkcję w ludzkiej egzystencji, mianowicie uczą pokory $^{9}$. Na takim tle Grzegorz nadaje nową wartość chorobie, ubóstwu i cierpieniu, funkcjonalizując je:

Dlatego ani nie podziwiajmy wszelkiego zdrowia, ani nie pogardzajmy chorobą, ani do przemijającego bogactwa nie przywiązujmy się sercem bardziej, niż wypada, i nie skłaniajmy się do tego, co jest zmienne i nietrwałe, zużywając na to jak gdyby część duszy; ani nie buntujmy się przeciw ubóstwu, jako przeciw cząstce zupełnie godnej wzgardy, potępionej i znienawidzonej, lecz umiejmy gardzić i nierozumnie użytkowanym zdrowiem, którego owocem jest grzech, i szanować

9 „A mówię to dlatego, ponieważ nie mogę was jeszcze przekonać, że niekiedy smutek jest cenniejszy od radości, przygnębienie od świątecznej radości, a chwalebna łza - od nieprzystojnego śmiechu" (Grzegorz z Nazjanzu, 13). 
chorobę cierpianą zbożnie, czcząc tych, którzy odnieśli zwycięstwo przez cierpienie, by przypadkiem wśród chorych nie ukrył się jakiś Job, o wiele czcigodniejszy od zdrowych, choćby zeskrobywał z ran ropę i pod gołym niebem spędzał nędznie noc i dzień, gnębiony i przez chorobę, i przez żonę, i przez przyjaciół. Odprawmy też niesprawiedliwe bogactwo, z powodu którego bogacz słusznie się męczy w płomieniu i żebrze o małą kroplę na odświeżenie języka, a chwalmy wdzięczną i cierpliwie znoszoną nędzę, z którą Łazarz zostaje zbawiony i ma bogactwo odpoczynku na łonie Abrahama (Grzegorz z Nazjanzu, 34).

Poprzez tego rodzaju stwierdzenia Grzegorz dokonuje radykalnego przewartościowania dotychczasowych pojęć. Podczas gdy w społeczeństwie antycznym choroba, ubóstwo i cierpienie miały zazwyczaj negatywny wydźwięk i były wykluczane poza jego margines, Grzegorz ukazuje je nie tylko jako charakterystyczną cechę ludzkiej stworzoności, lecz także jako nieodzowne w obiektywnej samoocenie każdego człowieka. Nie oznacza to w żadnym wypadku gloryfikacji choroby, ubóstwa i cierpienia. Niemniej obcowanie z potrzebującymi nabiera przez to pozytywnego charakteru.

Takie pozytywne spojrzenie na ubogich widać również w wygłoszonej przez Jana Chryzostoma, kilka lat później w Antiochii, Mowie o jałmużnie. Wyjaśnia w niej Pawłowe wezwanie założonych przezeń Kościołów do zbiórki na rzecz najstarszej gminy w Jerozolimie (zob. 2 Kor 8-9). To, że Paweł, wzywając do jałmużny, nie mówi o żebrakach i biedakach - takie określenia naznaczyłyby ich negatywnie - lecz o świętych, każe Złotoustemu spojrzeć na potrzebujących od strony ich wnętrza. Według niego, Apostoł Narodów powiedział tak, aby „,nauczyć słuchaczy szanowania biedaków, którzy są pobożni, i gardzenia bogaczami, kiedy lekceważą cnotę" (Jan Chryzostom, 1). To nie bogactwo, lecz pobożność i cnotliwość mają zatem prawdziwą wartość. Do tego - jak zaznacza w dalszej części swojej mowy - Bóg w porządku dzieła stworzenia przewidział ubóstwo, mimo że mógł, gdyby tylko chciał, uczynić cały świat bogatym. Ubóstwo przyczynia się mianowicie do rozwoju cnoty (tu Chryzostom jest znowu bardzo blisko argumentacji Grzegorza z Nazjanzu) i to zarówno po stronie dającego, jak i przyjmującego. Dlatego mówi, że Bóg „wielu zostawił w ubóstwie, tak dla ich dobra, jak dla twojego. Albowiem do osiągnięcia cnoty sposobniejsze jest ubóstwo od bogactwa, a tym, co tkwią w grzechach, niemała pociecha przychodzi ze wspomagania potrzebujących" (Jan Chryzostom, 5). Kiedy więc Chryzostom mówi pozytywnie o ubogich, to ma przy tym na myśli tamto soteriologiczne uzasadnienie jałmużny ${ }^{10}$.

To odwrócenie wartości prowadzi jednak nie tylko do tego, że patrzy się na potrzebującego inaczej niż w świecie pogańskim. Nade wszystko postrzega

10 „Bądź przeto ludzki i łagodny dla współniewolnika, odpuść mu wiele grzechów” (Jan Chryzostom, 6). 
się odtąd w literaturze kościelnej pozytywnie miejsca wyróżniające się działalnością charytatywną. Wielki projekt diakoniczno-charytatywny św. Bazylego w Cezarei Kapadockiej został ukazany przez jego przyjaciela, Grzegorza z Nazjanzu, nie jako powód wstydu dla społeczeństwa, lecz jego autentyczny skarb (por. Ambroży z Mediolanu, II 28. 140). Sam Bazyli mówił o swojej placówce jako „ozdobie dla całej miejscowości” (niestety nie uzasadnił tego). Myśl ta pojawia się jeszcze wyraźniej u Chryzostoma w jego Mowie o jałmużnie, kiedy posługując się słowami św. Pawła: „Wy zaś, bracia, nie ustawajcie, czyniąc dobrze" (2 Tes 3,13), wzywa do dobroczynności:

\begin{abstract}
„Ale jaką mają wymówkę przyzwoitą?” - powiesz. „Są to jacyś zbiegowie, obcy, biczowane łotry, co opuściwszy swoje miasta rodzinne, spływają do naszego". - Więc ty dlatego się oburzasz - powiedz mi - i rozskubujesz wieniec naszego miasta, że wszyscy je uważają za wspólną przystań i, choć obce, przenoszą nad rodzinne? Przecież z tego powodu należało się cieszyć i radować, że do waszych rąk, jakby do wspólnego spichlerza, wszyscy biegną i to miasto uważają za wspólną matkę. Nie psujcie tedy tej pochwały i nie kaleczcie starodawnego uznania, odziedziczonego po ojcach! (Jan Chryzostom, 6).
\end{abstract}

Jan uzasadniał swoje stanowisko tradycją ze swojego rodzinnego miasta Antiochii. Czy to fascynujące uzasadnienie dobroczynności wywarło jakiś wpływ na elity niechrześcijańskie? Jest to raczej wątpliwe. Niemniej w literaturze patrystycznej znajdujemy argumentację, która mogłaby być do przyjęcia także w kręgach pogańskich.

\title{
IV. Niereligijne argumenty za dobroczynnością
}

Grzegorz z Nazjanzu nie uzasadniał jednak działalności charytatywnej wyłącznie na podstawie swojej antropologii i przedefiniowania wartości. Nie była ona też dla niego jedynie sposobem naśladowania Chrystusa ${ }^{11}$. Jego spojrzenie na dobroczynność miało raczej charakter transreligijny. Według niego, była ona głęboko zakorzeniona w ludzkiej naturze. Grzegorz sięgnął przy tym po argumenty niemalże utylitarystyczne, zdroworozsądkowe, twierdząc, że ludzie są miłosierni także i przez to, że sami mogą znaleźć się w sytuacji, gdzie będą potrzebować aktów miłosierdzia ze strony innych. W swojej XIV mowie, odpowiadając na pytanie, czy wolno zaniedbywać potrzebujących, mówił:

${ }^{11}$ Grzegorz pisze dalej, że dobroczynność jest uczestnictwem w życiu Boga: „Stań się dla nieszczęśliwego Bogiem, naśladując miłosierdzie Boskie!” (Grzegorz z Nazjanzu, 26). Przejmuje on tu starożytną ideę naśladowania przez człowieka filantropii bogów. Dlatego mówi: „Nic bowiem tak właściwego Bogu nie ma człowiek, jak czynić drugim dobrze” (Grzegorz z Nazjanzu, 27). 
„Żadną miarą, bracia! Ani to nie przystoi nam, owieczkom Chrystusa i dobrego pasterza, który odszukuje zaginioną owcę, i pokrzepia słabą, ani nie odpowiada ludzkiej naturze, która współczucie uczyniła prawem, z równej dla wszystkich niemocy nauczywszy się szacunku i miłości ku ludziom" (Grzegorz z Nazjanzu, 15).

Także u Jana Chryzostoma - podobnie jak u Grzegorza z Nazjanzu - znajdziemy całkowicie inne niż wewnątrzreligijne linie argumentacyjne w odniesieniu do dobroczynności. W centrum jego argumentacji stoi wstyd, jaki ludzie powinni odczuwać z powodu swojej zatwardziałości i bezduszności. Te nieludzkie postawy Chryzostom zilustrował za pomocą wnikliwej analizy życia społeczności ówczesnej Antiochii.

Na jej podstawie, Jan twierdził, że w mieście jest tyle bogactwa, że wystarczyłoby go dla wszystkich ludzi. Szacował, że jedna dziesiąta jego mieszkańców jest bardzo bogata, a jedna dziesiąta tak biedna, że nie ma nawet tego, co niezbędne do życia. Pozostałe $80 \%$ to klasa średnia. Chryzostom pisał tak:

Mało jest ludzi bardzo bogatych, ale wielu takich, którzy idą po nich; ubogich natomiast o wiele mniej aniżeli tych. A jednak wielu z nich kładzie się spać z pustym żołądkiem, choć tak wielu jest ludzi, którzy mogliby nakarmić głodnych nie dlatego, że ci, którzy mają, nie mogli z łatwością dostarczyć im tego, co potrzeba, lecz dlatego, że są okrutni i nieludzcy. Gdyby bogaci i ci, którzy mają średni majątek, podzieliliby między siebie tych, którzy potrzebują chleba i odzieży, to zaledwie jeden ubogi wypadałby na pięćdziesięciu, a może nawet na stu. A jednak żyją oni w nędzy, mimo tak wielkiej liczby tych, którzy mogą dostarczyć potrzebnych rzeczy (Jan Chryzostom, 66,3).

O potrzebie indywidualnego wsparcia dla potrzebujących świadczą - według Jana Chryzostoma - już same liczby: obfitujący w dobra nie odczuliby żadnej straty. Wystarczyłoby, gdyby podzielili się chociaż z biednymi swoimi zyskami z odsetek (Jan Chryzostom 66). Za pomocą takich analiz Chryzostom apelował zatem o hojność.

W literaturze Kościoła starożytnego, obok argumentacji ukierunkowanej na indywidualną dobroczynność, można znaleźć jeszcze motywację związaną z diakonią instytucjonalną.

\section{Międzyreligijna konkurencja: niewypowiedziany argument}

„Pozyskujcie sobie przyjaciół niegodziwą mamoną” (Łk 16,9). To Jezusowe wezwanie nie pojawia się, co prawda, wprost w starożytnych źródłach jako argument za dobroczynnością, niemniej w wielu z nich obecna jest myśl, 
że dysponowanie i zarządzenie pieniędzmi przeznaczonymi dla biednych i potrzebujących oznacza władzę i wpływy. Z tego też powodu w III wieku biskupi coraz bardziej marginalizowali posługę wdów w Kościele. Działo się tak prawdopodobnie dlatego, że chodząc po domach, udawało się im zebrać fundusze na biednych znacznie większe niż te, które wpływały do biskupiej kasy. Walka o władzę i wpływy powodowała konflikty nie tylko wewnątrz wspólnot chrześcijańskich, lecz także na zewnątrz - w spotkaniu z innymi niekościelnymi instytucjami. Ślady tej konkurencji znaleźć można w literaturze pogańskiej. Na przykład, cesarz Julian, który odstąpił od chrześcijaństwa, widział w atrakcyjności chrześcijańskiej dobroczynności zagrożenie dla pogaństwa. W swoim liście (84) z 362 roku wzywał Arsakiosa, arcykapłana Galacji, do zakładania w każdym mieście gospód dla przyjezdnych ( $\xi \varepsilon v o \delta o \chi \varepsilon i ́ \alpha)$, aby każdy mógł skorzystać z pogańskiej filantropii (zob. Kislinger 1984). Julian próbował zatem przeciwstawić chrześcijańskiej idei akcent pogański. Wiedząc dobrze o publicznym charakterze chrześcijańskiej dobroczynności, zwłaszcza o dawaniu schronienia obcym i obowiązku grzebania umarłych, cesarz nie tylko zobowiązał pogańskich kapłanów Galacji do podobnych działań, lecz także sam ofiarowywał im hojne datki, aby spożytkowali je na opiekę nad ubogimi, obcymi i żebrakami. Wspólnoty pogańskie miały się natomiast do tego dokładać. „Hańbą bowiem jest dla nas - pisał Julian - że z Żydów nikt nie żebrze i że niewierni Galilejczycy oprócz swoich żywią także naszych, nasi zaś nawet swoim proszącym pomocy nie udzielają" (Julian Apostata, 39, 84). Jak widać, na płaszczyźnie instytucjonalnej presja konkurencji motywowała do działalności charytatywnej.

Grzegorz z Nazjanzu nazwał działania Juliana „szachrajstwem”, gdyż były one w gruncie rzeczy tylko „papugowaniem” chrześcijańskich praktyk (zob. Grzegorz z Nazjanzu, 4.) Niemniej zarówno przykład Juliana, jak i wiele innych problemów społecznych późnego antyku, pokazują, że nie tylko zarządzanie przez biskupa datkami na biednych, lecz także zakładanie instytucji charytatywnych, to obszary walki o władzę i wpływy. W szczególności motywacja do instytucjonalnego zaangażowania na rzecz potrzebujących brała się - jak często w starożytności - z chęci zdobycia prestiżu u dostojników kościelnych i wywierania osobistego wpływu na życie Kościoła i społeczeństwa.

\section{Zakończenie}

Czy można mówić o specyficznie chrześcijańskich motywach dobroczynności? Czy współczesną diakonię można oprzeć na motywach, którymi kierował się Kościół starożytny? 
Odpowiedź na te pytania wymaga przypomnienia omówionych tu biblijnych motywów i wzorców działalności diakonicznej. Wszystkie one mają dla niej znaczenie fundamentalne, jednakże głównie w przestrzeni wewnątrzchrześcijańskiej. Dla coraz bardziej sekularyzującego się otoczenia mogą być one trudne do przyjęcia.

Argumentacja soteriologiczna nie ma szans na pozytywną recepcję w kręgach ewangelickich i dlatego nie może być dla nich umotywowaniem współczesnej diakonii. $Z$ konkurencją pomiędzy różnymi instytucjami dobroczynnymi mamy do czynienia także i dzisiaj. Może ona być zatem niewypowiedzianym argumentem za zaangażowaniem Kościoła instytucjonalnego na rzecz diakonii. Jeśli jednak diakonia chce zachęcić jednostki do włączenia się w jej działania, to powinna sięgnąć przede wszystkim po te starożytne argumenty, które były związane z przedefiniowaniem wartości oraz z ogólnie przyjętymi wzorcami zachowań w społeczeństwie.

Chrześcijański obraz człowieka, który zwraca się w stronę potrzebujących nie tylko ze współczucia czy z czysto zdroworozsądkowych kalkulacji, jest jednym z najmocniejszych uzasadnień diakonicznego zaangażowania. Dopiero wtedy, gdy potrzebujący przestaną być postrzegani jako ,istoty upośledzone", lecz jako stworzeni na obraz i podobieństwo Boże, może być mowa o działalności charytatywnej we właściwym tego słowa znaczeniu. Tylko wtedy da się też zrozumieć, dlaczego jakieś miasto czy społeczność wyróżnia się filantropią. Jednakże przyjęcie dzisiaj motywacji opartej na takim obrazie człowieka wymaga oczywiście akceptacji tego obrazu.

Silnymi motywami działalności charytatywnej mogą być również w naszych czasach - jak już nauczali ojcowie Kościoła późnego antyku, zwłaszcza Jan Chryzostom - twarde statystyki podziału środków pomocy i wstyd odczuwany z powodu niesprawiedliwości.

Szczególnie mocnym uzasadnieniem działań charytatywnych może być także dzisiaj i w przyszłości powiązanie motywów religijnych i niereligijnych z uwzględnieniu jednak chrześcijańskiego obrazu człowieka. W tym sensie możemy powtórzyć teraz zacytowane na początku tego artykułu słowa św. Cypriana z Kartaginy: „Zaiste, bracia najmilsi, miłosierdzie - to cnota prawdziwie Boskiej wspaniałości!”

(Z języka niemieckiego przełożył ks. Adam Kalbarczyk)

\section{BIBLIOGRAFIA}

Ambroży z Mediolanu (1967): Obowiazki duchownych. Tłum. K. Abgarowicz. Warszawa. Atanazy Aleksandryjski (2017): Żywot św. Antoniego Wielkiego. Tłum. E. Dąbrowska. Kraków. Cyprian (2015): O uczynkach miłosiernych i jałmużnie. Kraków. 
Garrison R. (1993): Redemptive Almsgiving in Early Christianity. „Journal for the Study of the New Testament". Suppl. Ser. 77.

Grzegorz z Nazjanzu (1967): Mowy wybrane. Warszawa.

Harnack A. (1902): Mission und Ausbreitung des Christentums. T. 1. Leipzig.

Jan Chryzostom (2001): Homilie na Ewangelię wedlug św. Mateusza. Cz. 2: Homilie 41-90. Tłum.

A. Baron i J. Krystyniacki. Kraków.

Jan Złotousty (1947): Dwadzieścia homilij i mów. Tłum. T. Sinko. Kraków.

Julian Apostata (1962): Listy. Tłum. W. Klinger. Wrocław-Warszawa-Kraków.

Kislinger E. (1984): Kaiser Julian und die (christlichen) xenodocheia. W: W. Hörander, J. Koder,

O. Kresten, E. Trapp (red.), Byzantios. Festschrift Für Herbert Hunger Zum 70. Geburtstag s. 171-184. Wien.

Noormann R. (2010): Secundum euangeli legem. Die biblische Begründung des Bußverfahrens zur Wiederaufnahme abgefallener Christen bei Cyprian von Karthago. „Römische Quartalschrift” 105: 2010 s. 169-191.

Pierwsi świadkowie. Pisma Ojców Apostolskich (1998). Tłum. A. Świderkówna. Kraków.

\section{S T R E S Z C Z E N I E}

Niniejszy artykuł przedstawia w sposób systematyczny uzasadnienie dobroczynności, jakie dawało wielu ojców Kościoła - począwszy od Cypriana z Kartaginy w swoich mowach i pismach na temat jałmużny i uczynków miłosierdzia. Kościół starożytny posługiwał się licznymi tekstami biblijnymi dla uzasadnienia dobroczynności. W wielu z nich znajdziemy bezpośrednie wezwania do indywidualnego zaangażowania charytatywnego. Taka motywacja czyni jednak z diakonii formę sprawiedliwości z uczynków, która jest nie do przyjęcia dla protestantów. Niemniej w nauczaniu ojców Kościoła znaleźć można również takie linie argumentacji, które zwrócone są przede wszystkim w stronę adresata dobroczynności, oparte na chrześcijańskiej antropologii. Obok takiej argumentacji spotkać można także uzasadnienia związane z diakonią instytucjonalną, w ramach której do działalności charytatywnej mogła pobudzać presja międzyreligijnej konkurencji, a także chęć zdobycia prestiżu u dostojników kościelnych i wywierania osobistego wpływu na życie Kościoła i społeczeństwa.

Słowa kluczowe: dobroczynność; Kościół starożytny; motywacja; Kościół ewangelicki

\section{THE MOTIVES OF CHARITABLE ACTIVITY IN THE ANCIENT CHURCH}

\section{S UM M A R Y}

The article gives a systematic justification of charitable activity following the teaching of many Church Fathers on this issue - from Cyprian of Carthage onward - contained in their orations and writings on almsgiving and works of charity. The 
ancient Church used numerous biblical texts to justify charity, and in many of them we can find a direct appeal for individual commitment to charitable acts. Albeit such a motivation makes diakonia a form of righteousness by works, which is unacceptable to Protestants, in the teaching of the Church Fathers one also discovers lines of argumentation focused on the addressees of charity and based on Christian anthropology. Apart from arguments of this type there are also modes of justification of charity connected to institutional diakonia which was likely to be driven by the pressure of interreligious competition, pursuit of prestige by Church dignitaries and their desire to exert a personal influence over the life of the Church and society.

Keywords: charity; ancient Church; motivation; Evangelical Church
ANDREAS MüLLER - prof. dr hab., duchowny ewangelicki, profesor historii religii i Kościoła pierwszego tysiąclecia, prodziekan Wydziału Teologicznego Uniwer- sytetu Christiana Albrechta w Kilonii; e-mail: AMueller@kg.uni-kiel.de. 